\title{
Optimization Comparison of Stand-Alone and Grid-Tied Solar PV Systems in Rwanda
}

\author{
Samuel Bimenyimana ${ }^{1 *}$, Godwin Norense Osarumwense Asemota ${ }^{2}$, Paula Jeanne Ihirwe ${ }^{3}$ \\ ${ }^{1}$ State Key Laboratory of Reliability and Intelligence of Electrical Equipment, Department of Electrical Engineering, \\ Hebei University of Technology, Tianjin, China \\ ${ }^{2}$ African Centre of Excellence in Energy for Sustainable Development, University of Rwanda, Kigali, Rwanda, Kigali, Rwanda \\ ${ }^{3}$ Department of Management and Economics, MBA Program, Tianjin University, Tianjin, China \\ Email: `s0785213122@gmail.com, asemotaegno@gmail.com,paulaihirwe90@gmail.com
}

How to cite this paper: Bimenyimana, S., Asemota, G.N.O. and Ihirwe, P.J. (2018) Optimization Comparison of Stand-Alone and Grid-Tied Solar PV Systems in Rwanda. Open Access Library Journal, 5: e4603. https://doi.org/10.4236/oalib.1104603

Received: March 19, 2018

Accepted: May 20, 2018

Published: May 23, 2018

Copyright (C 2018 by authors and Open Access Library Inc.

This work is licensed under the Creative Commons Attribution International License (CC BY 4.0).

http://creativecommons.org/licenses/by/4.0/

\section{(c) (i) Open Access}

\begin{abstract}
Solar power has gained great usage in electricity generation world-wide, and stand-alone is common in Rwanda. Site visits and energy audit estimates for a typical residential house in Rwamagana district, were used to cost effectively compare stand-alone and grid-tied PV systems able to supply $7.2 \mathrm{kWh} /$ day, load. Algorithms design of lifetime costs and benefits were developed, to analyse total daily energy requirements using Frequentist approaches to obtain the Kullback-Liebler solution for convexity. The Frequentist inference approaches adopted for study led to optimal solution of the design problem. Results show that stand-alone PV system needs 17 modules with US\$ 15,932 initial investment and 18.1 years payback period while grid-tied PV system requires 8 modules, with US $\$ 4449$ investment, and 5.7 years payback. Once government adopts smart grid technology with mature [1] feed-in-tariff, grid-tied solar power systems [2] can be used to increase electricity supply in Rwanda through domestic energy producers, because of lower initial investment costs and shorter payback periods.
\end{abstract}

\section{Subject Areas}

Electric Engineering, Engineering Management

\section{Keywords}

Bayesian Probabilities, Frequentist Approach, Payback Period, Significance Criterion, Virtual Battery

\section{Introduction}

Rwanda's geography is represented by savannah climate with $5 \mathrm{kWh} \cdot \mathrm{m}^{2} /$ day of 
solar radiation intensity, and peak sun hours nearly 5 hours per day, which indicate energy from solar systems would be abundant and reliable once properly exploited [3]. Rwanda installed electricity generation capacity (216 MW) is low and a small percentage of population has access to utility grid [4]. Rwanda Energy Group (REG), its partners and energy investors are using their best efforts to increase electricity generation and access to all Rwandan residents [5]. Solar systems are mostly installed in rural areas where there is limited grid access and some urban areas, as stand-alone systems [3] [6]. Photovoltaic (PV) modules and other devices produce electricity through direct transformation of sunlight into electricity, without mechanical moving parts, no high maintenance costs and no climatic pollutions [7]. Stand-alone solar power system also called off-grid solar power system, consists of solar photovoltaic panels, charge controllers, battery, inverters, cables and other equipment assembled together to generate electricity to users, independent of utility grid or other energy sources [7]. Therefore, utility interactive, grid intertie and grid back-feeding solar power systems indicate grid-tied solar power systems, where users interact with utility grid either by selling excess electricity to or buying from it, when needed [8]-[13]. It is hypothesised that the grid connected solar power system has lower cost and shorter payback period than stand-alone system, for residential houses in Rwanda. This paper is organized into: introduction, types of solar power systems, methodology, results and discussions, conclusion and recommendations.

\section{Types of Solar Power Systems}

Solar power systems transform sunlight energy into electricity using either photovoltaic systems or concentrated solar power [14] [15] using photovoltaic effect [16] [17]. Photovoltaic solar systems comprise devices and equipment like photovoltaic modules, charge controllers, inverters, batteries or battery bank [18]. Their design and cost estimation, depend on installation site, building design, required load profile and type of solar module [19]. Depending on application and usage, they can be classified as stand-alone systems or off grid solar power systems; grid-tied and hybrid solar power systems. They can also appear as: 1) Grid connected with battery storage, 2) Stand-alone off-grid Hybrid systems, 3) Portable solar power systems, 4) Solar batteries-Off-grid and 5) Hybrid solar power systems [7] [8]. However, grid connected solar power systems and stand-alone off-grid solar power systems, are compared in this paper. Grid-Tied systems are designed to operate in parallel with and interconnected with the electric utility grid while Stand-alone systems are designed to operate independent of the electric utility grid, and are generally designed and sized to supply certain DC and/or AC electrical loads [18].

\subsection{Stand-Alone Solar Power System}

Sunlight shines on solar PV modules and generate electricity through photovoltaic effect [20] [21]. Charge controllers are connected across solar PV modules to 
prevent overcharging, overvoltage and quick discharge of battery [22] [23]. Generated electricity is stored in battery and some DC loads can be powered from this electricity in battery [24] [25] [26]. Electricity in battery also passes through inverter and is converted into AC electricity to be used by AC loads [27] [28]. Solar energy is used in solar lanterns, solar home lighting and solar water pumping systems [29]. Solar power systems connection technology enables them work as: 1) Stand-alone solar power system supplying only DC loads, 2) Stand-alone solar power system with electronic control circuit to extend its duty cycle, 3) Stand-alone solar power system supplying DC loads, electronic control circuit for extending duty cycle and simultaneously charging storage battery for power supply at night or whenever there is no sunlight, and 4) Stand-alone solar power system with DC/AC converter, which supply AC loads, supplies electronic control circuit for duty cycle extension and simultaneously charging storage battery for emergency supply. Therefore, stand-alone solar systems are mostly installed in remote areas without utility grid access. Batteries and other equipment needs, make them more expensive than grid-tied solar power systems, because of more maintenance and battery replacement costs after 7 - 10 years [7]. Advantageously, stand-alone solar power owners pay no monthly electricity bills because the equipment completely belongs to them after defraying installation costs [30] [31].

\subsection{Grid-Tied Solar Power Systems}

DC electricity generated by solar modules passes through grid-tied inverter and is converted to AC electricity, which can be used by home electric appliances or directly fed into utility grid through a net-meter or a bi-directional meter [7]. Grid-tied solar power systems are cheaper and simpler than stand-alone solar systems because they do not need batteries and other expensive equipment, since the utility grid is the virtual battery bank [14] [32] [33] [34]. Grid-tied solar power systems are more cost effective and accepted, easy to operate with low maintenance, can be sized to meet any scale of power requirements, nor sized to meet peak loads demands as the excess electricity is fed into utility grid, and drawn from it, whenever, it is needed [7]. Grid-tied solar power owners save money using net meters, because they sell electricity to utility grid whenever their solar system produces more electricity than what their electrical appliances can consume. Conversely, utility grid supplies electricity to grid-tied solar power systems owners, whenever there was a deficit from solar power systems [35]. Mainly because the grid-tied solar power systems have no batteries, whenever there is no sunlight and utility grid is down, they would have no electricity, especially at nights [7] [31] [36] [37] [38].

\section{Methodology}

Site visits were made to Rwamagana district, where the sample residential house is located, and where utility grid access is possible for comparison. Agreements 
and discussions were made to compare both stand-alone and grid-tied solar power systems once installed in this residential house. The sample size chosen for this study was 1 in 20 residential houses, for the statistical power probability to be 0.05 . A significance criterion states how unlikely a result must be if null hypothesis is true, to be significant. For criterion of 0.05 , probability of achieving observed effect must be less than 0.05 for the null hypothesis to be true. Therefore, Frequentist approach to inference was invoked because it allows probabilities to have interpretations, which represent the researchers' beliefs that given values of parameters are true [39] [40] [41].

The residential house owner listed his electric household appliances together with their power rating and hours of use per day. For the stand-alone solar power system, design and cost estimation were conducted as follow [42] [43] [44]: 1) Calculated building load, 2) Choice of system voltage and components, 3) Solar PV array specifications and design, 4) Inverter capacity calculation, 5) Battery bank capacity determination, 6) Identification and choice of charge controllers specifications, 7) Cable sizing, and 8) Cost analyses.

The following abbreviations and formulae in the fourth section of this paper were used to design, size and cost, stand-alone solar PV system: $V_{d c}$ system dc voltage, $T_{s h}$ : daily average sun hours, $E_{d}$ : daily average energy demand, $E_{r \dot{d}}$ : required daily average energy demand, $n_{b}$ : battery efficiency, $n_{i}$ : inverter efficiency, $n_{c}$ : charge controller efficiency, $P_{\text {ave, peak }}$ : average peak power, $V_{b}$ : battery rated dc voltage, $I_{d c}$ : total system dc current, $N_{s m}$ : series modules number, $N_{p m}$ : parallel modules number, $V_{r m}$ : rated module voltage, $I_{r m}$ : rated module current, $N_{t m}$ : total modules number, $E_{\text {est }}$ estimated energy storage, $D_{\text {aut }}$ autonomy days, $E_{\text {safe }}:$ safe energy storage, $D_{\text {disch }}$ : discharge depth, $C_{t b}$ : total battery bank capacity, $N_{t b}$ : total batteries number, $N_{s b}$ : series batteries number, $N_{p b}$ : parallel batteries number, $I_{r c c}$ : desired charge controller current, $I_{s c}^{M}$ : selected module short circuit current, $I_{c a b}$ : cable current, $I_{o i}$ inverter output current, $V_{o i}$ inverter output voltage, $B_{\text {cost }}$ : battery cost, $C_{b}$ : selected battery capacity, $P_{\dot{i}}$ : inverter input power, $P_{\dot{f}}$ power factor $=0.8, N_{c c}$ charge controllers number, $C_{\text {tcost }}$ charge controllers total cost.

Consequently, the grid-tied solar PV power system was designed and estimated as follow: 1) We used total daily energy requirements (usage) of case study (7204 Watts/day), 2) Considered daily average peak sun hours for Rwanda (5 hours), and 3) Determined and sized solar system components assuming $100 \%$ generation capacity, which was also equal to $100 \%$ electricity consumption (No loss).

\subsection{Economic Valuation Indices for Solar Energy Projects}

Farhat and Reichelstein [45] used levelised cost and profitability of polygeneration to align both fuels and generated products on same per unit bases to reliably compare polygeneration with single-electricity generation using natural gas or wind alternatives. Net present value (NPV), profit index (PI), payout time, and cost of energy were used to evaluate energy economics, but none of these methods 
has produced consistency in comparison to cost-benefit. Furthermore, the cost of energy ( $(\$ / \mathrm{kWh})$ approach has the following drawbacks: 1$)$ It may not produce electricity as its end product, 2) It is difficult to obtain equivalent cost of non-electricity products in electricity cost quantities, and 3) Underestimation of actual cost of electricity [45].

Therefore, assessment of technological and economic effectiveness should combine operational valuation with economic trade-offs for economic gains. Hence, investment planning, trade-offs in operational flexibility, techno-economic analyses using input-output comparison coupled with process configuration, should be embraced for stand-alone and grid-tied solar PV systems [45]. Flexibility limits were imposed on optimized operations to determine operational constraints of solar electricity generation based on economics. These helped to determine profit margins and real options for valuation.

Also, breakeven calculation is the ratio of lifetime costs to lifetime solar electricity plant production [45]. The algorithms development for lifetime costs and lifetime stream of benefits for solar electricity plant production, follow.

The cost of solar electricity (PV) consists of capacity per unit output $C_{e}$, time averaged fixed operating cost per unit output $f_{e}$, and time averaged variable cost per unit of output $V_{e}$. So the cost of solar electricity generated from PV is:

$$
\mathrm{COEPV}=c_{e}+f_{e}+v_{e}
$$

The cost of capacity per unit kilowatt of solar electricity is:

$$
c_{e}\left(\$ / \mathrm{kW}_{\mathrm{e}}\right)=\frac{P_{e}}{n \cdot C F \cdot \sum_{j=1}^{Y} a_{j} \delta^{j}}
$$

where $P_{e}$ is price of unit capacity to deliver one kilowatt of solar electricity per hour. The components of this cost include procurement and construction, import duties, and other ancillary services. The stream of benefits yield of solar electricity from PV system is over $Y$ years, with $n \cdot a_{j} \cdot C F$ kilowatts for year $j$, $n=8760$ hours in any one year, $a_{j}$ is derating failure factor (ageing and solar technology dependent efficiency loss factor), $C F$ is capacity factor (fraction, because PV systems plant is not operated $100 \%$ at all times), $\delta$ is the discount factor, which is a decimal value multiplied against cash flow to discount it back to today's value (present value) [45] [46]. Furthermore, discount factor: 1) increases over time, as its decimal value becomes smaller, 2) provides explicit factors for each time period, to enable us see the effect of compounding more vividly, 3) makes discounted cash flow (DCF) model easier to audit and 4) is alternative to using either NPV or internal rate of return (IRR). And $\xi$ is the discount rate, which converts one-time costs into annualized costs [46].

The discount factor is [46]:

Discount factor $=1 /\left(1 \times(1+\text { Discount rate })^{\text {Period number }}\right)$

Accordingly, using the breakeven formula, a convenient discount factor for solar electricity projects comparison is [45]: $\delta=(1 / 1+\xi)^{2}$. Furthermore, fixed 
operating costs change yearly, and average fixed operating cost for producing one kilowatt of PV solar electricity incurred per year is $f_{e j}\left(\$ / \mathrm{kW}_{\mathrm{e}}\right)$. Fixed operating costs include, labor, administrative overheads, maintenance and insurance [45]. Costs are assumed proportional to installed capacity, and independent of actual solar electricity produced:

$$
f_{e}=\frac{\sum_{j=1}^{Y} f_{e j} \delta^{j}}{n \cdot C F \sum_{j=1}^{Y} a_{j} \delta^{j}}
$$

Conversely, variable costs change over time as ancillary loads, foreign exchange conversion expenses and interest charges [45]. Let $v_{e j}(t)\left(\$ / \mathrm{kW}_{\mathrm{e}}\right)$, be time-dependent variable cost of one kilowatt of solar electricity in year $j$ and, $v_{e j}\left(\$ / \mathrm{kW}_{\mathrm{e}}\right)$, yearly average variable cost, then yearly averaged variable cost becomes:

$$
v_{e j}=\frac{1}{n} \int_{0}^{n} v_{e j}(t) \mathrm{d} t
$$

Consequently, over project lifecycle, average time variable cost for $1 \mathrm{~kW}$ of solar electricity:

$$
v_{e}=\frac{\sum_{j=1}^{Y} v_{e j} n \cdot C F \cdot a_{j} \delta^{j}}{n \cdot C F \sum_{j=1}^{Y} a_{j} \delta^{j}}=\frac{\sum_{j=1}^{Y} v_{e j} a_{j} \delta^{j}}{\sum_{j=1}^{Y} a_{j} \delta^{j}}
$$

Similarly, $P_{e j}(t), P_{e j}$, and $P_{e}$ are respectively, time-dependent solar electricity price for year $j$, yearly average price of solar electricity in year $j$ and time averaged price for solar electricity. From breakeven analyses definition for COEPV, PV solar electricity production plant under investigation is cost-effective if and only if [45]:

$$
P_{e}>\mathrm{COEPV}
$$

Therefore, cost-effectiveness is measured by that quality of PV solar electricity plant, which sustains positive net present value (NPV), and equates with breakeven analyses.

\subsection{Frequentist Methodologies}

Frequentist designs focus on planning experiments through appropriate choices of sample sizes, whose long-run average actual accuracy equals long-run average reported accuracy [47]. The 95\% classical confidence interval of unknown success probability $\theta$, becomes Jeffreys equal-tailed $95 \%$ confidence interval:

$$
C^{J}(x)=\left(q_{0.025}(x), q_{0.975}(x)\right)
$$

where $q_{\alpha}(x)$ is $\alpha$ th-quantile of $\operatorname{Beta}(x+0.5,20.5-x)$ distribution. Applying the modified Jeffreys equal-tailed confidence interval for large $m$, and using local smoothing kernel over range $\theta \pm 2 \sigma$ supplies $\operatorname{Beta}(a(\theta), a(1-\theta))$ distribution $K_{\sigma, \theta}($.$) , where the frequentist coverage is 1-\alpha(\theta)$, and leads to $\sigma$-local average coverage: 


$$
\begin{aligned}
1-\alpha_{\sigma}(\theta)= & \int_{0}^{1}[1-\alpha(\theta)] K_{\sigma, \theta}(\theta) \mathrm{d} \theta \\
= & \sum_{x=0}^{n}\left(\begin{array}{l}
n \\
k
\end{array}\right)[\Gamma(a(\theta)+a(1-\theta)) \cdot \Gamma(a(\theta)+x) \cdot \Gamma(a(1-\theta)+n-x)] \\
& \cdot[\Gamma(a(\theta)) \Gamma(a(1-\theta)) \Gamma(a(\theta)+a(1-\theta)+n)]^{-1} \\
& \cdot \int_{C^{J *}} \operatorname{Beta}((\theta) \mid a(\theta), a(1-\theta)) \mathrm{d} \theta
\end{aligned}
$$

Equation (8) is beta-binomial predictive distribution, where $\operatorname{Beta}(\theta \mid a(\theta), a(1-\theta))$ is beta density function having specified parameters. Also, $\pi(\theta) \propto \theta^{-1 / 2}(1-\theta)^{-1 / 2}$ for $\theta$. These intervals consist of upper and lower $\alpha / 2$-quantiles of posterior distribution for $\theta$. Furthermore, for two-sided test of null hypothesis, $\theta_{*}=\left|\theta_{* *}\right|$, is absolute value of real parameter $\theta_{* *}$, so that $\ddot{\theta}_{*}=[0, \infty)$. But, $p(x)=S(0 ; x)$ is a two-tailed p-value for hypothesis testing, such that: $\theta_{* *}=0$. Also, $\ddot{P}_{*}\left(\ddot{\theta}_{*} \leq 0\right)=S(0 ; x)$, and

$$
\ddot{P}_{*}\left(\ddot{\theta}_{*} \leq 0\right)=\ddot{P}_{*}\left(\ddot{\theta}_{*}=0\right)
$$

$p(x)=\ddot{P}_{*}\left(\ddot{\theta}_{*}=0\right)$, is p-value, which is probability that null hypothesis is true [49] [67]. $\ddot{\tau}=\ddot{\theta}_{*} \rightarrow \theta$, is defined by

$$
\ddot{\tau}\left(\ddot{\theta}_{*}\right)=1_{(0, \infty)}\left(\ddot{\theta}_{*}\right)
$$

That means, $\ddot{\theta}=0$, if $\ddot{\theta}_{*}=0$. Also, $\ddot{\theta}=1$, if $\ddot{\theta}_{*}>0$. Therefore, $p(x)=\ddot{P}_{*}\left(\ddot{\theta}_{*}=0\right)$, which mandates, $\ddot{P}(\ddot{\theta}=0)=p(x)$, and by implication:

$$
\ddot{P}(\ddot{\theta}=1)=1-p(x)
$$

For normally distributed noise $\varepsilon \sim N\left(0, \sigma^{2}\right)$, the likelihood function is [48]:

$$
L(y \mid \theta)=\prod_{k=1}^{m} \prod_{l=1}^{d_{k}} \frac{1}{\sqrt{2 \pi \sigma_{k l}^{2}}} \exp \left(\frac{-1}{2}\left(\frac{y_{k l}-y_{k}\left(t_{l}, \theta\right)}{\sigma_{k l}}\right)^{2}\right)
$$

where $m$ model outputs $y_{k}\left(t_{l}, \theta\right)$ and $d_{k}$ data instants, at such time points $t_{l}$. The maximum of $L(y \mid \theta)$, which is best model fit to data, gives point estimate $\hat{\theta}$ of parameters[48]. The threshold $\Delta_{\alpha}=Q\left(\chi_{d . f}^{2}, \alpha\right)$, is a quantile of $\chi^{2}$-distribution with degrees of freedom (d.f), and confidence intervals determined through profiles:

$$
\left\{\theta_{i} \mid-2 \log \left(P L\left(y \mid \theta_{i}\right) \mid L(y \mid \hat{\theta})\right)<\Delta_{\alpha}\right\}
$$

While penalisation removes difficulties in stability of parameter estimates, shrinks semi-Bayes or partial Bayes estimation without satisfying Bayesian requirements, it allows us tolerate degrees of bias as a trade-off for parameter variability estimates [49]. Therefore, the Penalised log-likelihood becomes [49]:

$$
\ln \{L(\beta ; y)\}-r(\beta-m)^{2} / 2
$$

where, $r / 2$ is penalty weight factor relative to original log-likelihood, $m$ is bases for good value information and $\beta$ are unknown parameters. However, every statistically significant result is subject to a type-I error, of falsely rejecting the null hypothesis as no bias in point estimates. In multilevel analyses with a few clus- 
ters (as in this study), [50] assert that frequentist methods provide unbiased estimates and accurate inference. Thus, results are more precise as they occupy narrower bands, while parameter bias estimate magnitudes shrank towards zero.

\subsection{Confidence Benchmark Posterior and Convex Functions Analyses}

While posterior distribution is chosen by nature for priors, statisticians choose parametric distributions to maximise minimum Kullback-Liebler information [51], acquired over a confidence distribution. Bayesian methodology is used when prior distribution is determined from relative frequencies, and Frequentist approaches are used without knowledge of such parameter distributions. The condition for total ignorance of prior distribution has a lower bound of 0 , and $\mathrm{p}$-value is used in place of any posterior probability. Whenever prior distribution is completely known, posterior is used for inference, representing a higher bound of 1 [47] [51] [52] which is a convex set ( 0,1 problem). From hindsight, convex functions are always minimising and lead to optimal solutions in the interval of convexity, with one minimum [52] [53]. The analyses follow.

We define $H$ as the Hessian, $H_{r}$ as the relaxed Hessian, $L$ as the Lagrangian and $L_{r}$ is the relaxed Lagrangian (it is the largest functional below $L$ ). Assuming the minimum cost occurs when $\delta \leq 1$. It means: 1$)$ Minimum cost $E^{\prime}$ cannot be less than the project cost $E$, because $H_{r} \leq H$ as $L_{r} \leq L$ for each non-negative $\lambda$ and $\mu$,2) $H_{r}$ is polyconvex as its functional is minimum, 3) The constrained minimum cost $E^{\prime}$ equals $E$. Furthermore, the minimising functions represent weak oscillatory limits for $L$. But, $H_{r}$ is polyconvex and $H_{r} \leq H$ [52] [53]. The proof of polyconvexity using convex functions shows that multilinear functions, which envelope is $H_{r}$ is actually below $H$, and it is also minimising. Therefore, [52]:

$$
d(\rho)=\left\{\begin{array}{l}
2 \rho, 0 \leq \rho \leq 1 \\
1+\rho^{2}, \rho \geq 1
\end{array}\right.
$$

The square root of $\rho$ is a convex function and $d(\rho)$ is also convex and increasing. The composition of $d(\rho)$ is also convex. The linear Jacobian terms $\mp 2 J$, leave $H_{ \pm}$convex as functions with extra arguments. But, $H_{r}$ is maximum of the two functions, $H_{ \pm}$and whenever $J$ is identified with $\operatorname{det}[\nabla u \nabla v], H_{r}$ must, therefore, be polyconvex [52]. Also, $d(\rho)=1+\rho^{2}$ and for large $\rho$, the $H_{ \pm}$functions become: $1+|\nabla u|^{2}+|\nabla v|^{2}$. For small $\rho$, the comparison between $H_{+}$and $H_{-}$ depends on:

$$
2(m+n)^{1 / 2}-n \geq 2(m-n)^{1 / 2}+n
$$

The above inequality holds for: $m \geq n \geq 0$ and, $m+n \leq 1$. So, $m=|\nabla u|^{2}+|\nabla v|^{2}$ and $n=2|J|$. The maximising choice of sign is that for which $\pm \operatorname{det}[\nabla u \nabla v]$ equals $|J|$. The argument $\rho$ is exactly $\gamma$ in the definition of $H_{r}$, where $\max H_{ \pm}$coincides with $H_{r}$ [52] [53]. However, $H_{r}$ is below and less than $H$ mainly because $2 \rho$ is below and less than $1+\rho^{2}$. The difference: 
$(1-\rho)^{2}=(1-\gamma)^{2}$ in the range $0<\gamma<1$, is the saving in investment cost that was achieved through homogenisation and convexification of the solar PV system.

\section{Results and Discussion}

The case study residential house owner's electrical appliances were listed together with their power ratings and time of use per day. The total load profile was determined to be 7204 Watts-hour/day by adding up the daily electricity consumption of each appliance (Table 1 ).

\subsection{Stand-Alone Solar PV System Design and Cost Estimation}

We designed PV systems choosing the type of photovoltaic module and some system parameters. Znshine PV-Tech ZX250 (48) MS module [54] was used having the following specifications on nameplate: $V_{r m}=V_{m p}=48.7 \mathrm{~V}$, $I_{r m}=I_{m p}=5.14 \mathrm{~A}, V_{o c}=59.6 \mathrm{~V}, I_{s c}=5.49 \mathrm{~A}$ and each $\mathrm{PV}$ module costs US $\$ 375.00$ (Table 2). Efficiency was estimated to be $0.85,0.9$ and 0.9 respectively for batteries, charge controllers and inverters. The system voltage was set to 24 $V_{d c}$ and 5 hours was the average peak sun-hours per day in Rwanda [3].

The MK 8A8DLTP-DEKA 12V 245Ah AGM Battery, able to support PV array was selected with parameters: $C_{b}=245 \mathrm{Ah}, V_{b}=12 \mathrm{~V}, D_{\text {disch }}=80 \%, B_{\text {cost }}=$ US\$588.00, $D_{\text {autonomy }}=2$ days [55] (Table 3 ).

The Morningstar TS-MPPT-60 Tristar Mppt 60A charge controller was selected, with specifications: $I_{c c}=60 \mathrm{~A}, C_{\text {cost }}=\mathrm{US} \$ 598$, safe factor $\left(F_{\text {safe }}\right)=1.25$ [56] (Table 4).

During inverter sizing and design, power ratings of appliances that may run simultaneously were added as follow: $P=(96+210+75+15+1100+250+15+$ $25+150) \mathrm{W}=1936 \mathrm{~W}$ (non-inductive loads) and appliances with large surge

Table 1. Residential house electrical appliances and their daily load profile.

\begin{tabular}{cccccc}
\hline No. & Appliance & Quantity & $\begin{array}{c}\text { Power } \\
\text { rating } \\
{[\mathrm{W}]}\end{array}$ & $\begin{array}{c}\text { Hours of use } \\
\text { per day }\end{array}$ & $\begin{array}{c}\text { Energy use per } \\
\text { day[W/day] }\end{array}$ \\
\hline 1 & $\begin{array}{c}\text { Compact } \\
\text { Fluorescent Lamp }\end{array}$ & 14 & 15.0 & 12.0 & 1440.0 \\
2 & Computers (laptop) & 3 & 25.0 & 5.0 & 840.0 \\
3 & Washing machine & 1 & 245.0 & 5.0 & 375.0 \\
4 & Shaver & 1 & 15.0 & 0.6 & 1225.0 \\
5 & Iron & 1 & 1100.0 & 0.6 & 9.0 \\
6 & TV & 2 & 125.0 & 6.0 & 660.0 \\
7 & Cell phone & 6 & 2.5 & 7.0 & 1500.0 \\
8 & Satellite receiver & 1 & 25.0 & 24.0 & 600.0 \\
9 & Refrigerator & 1 & 150.0 & 3.0 & 450.0 \\
& & Total Load Profile $=\mathbf{7 2 0 4 . 0}$ & \\
\hline
\end{tabular}


Table 2. Photovoltaic array design and cost estimation.

\begin{tabular}{ccc}
\hline Parameter & Formula to be used & Computed parameters \\
\hline Required Daily Energy Demand: $E_{r d}$ & $E_{r d}=\frac{E_{d}}{n_{i} n_{b} n_{c}}$ & $10.463 \mathrm{kWh} /$ day \\
Average peak power: $P_{\text {ave } \text { Peak }}$ & $P_{a v e, \text { Peak }}=\frac{E_{r d}}{T_{s h}}$ & $2092.6 \mathrm{~W}$ \\
Total Dc current: $I_{d c}$ & $I_{d c}=\frac{P_{a v, P e a k}}{V_{d c}}$ & $87.19 \mathrm{~A}$ \\
Number of series modules: $N_{s m}$ & $N_{s m}=\frac{V_{d c}}{V_{r m}}$ & 1 \\
Number of parallel modules: $N_{p m}$ & $N_{p m}=\frac{I_{d c}}{I_{r m}}$ & 17 \\
Total number of modules: $N_{t m}$ & $N_{t m}=N_{s m} \times N_{p m}$ & 17 \\
Total cost of the array & Array cost $\times$ Module cost & US $\$ 6375.00$ \\
\hline
\end{tabular}

Table 3. Battery design and its cost estimation.

\begin{tabular}{ccc}
\hline Parameter to be determined & Formula & Computed parameters \\
\hline Estimated Energy storage: $E_{e s t}$ & $E_{e s t}=E_{d} \times D_{a u t}$ & $14.408 \mathrm{kWh}$ \\
Safe Energy storage: $E_{s a f e}$ & $E_{s a f e}=\frac{E_{e s t}}{D_{d i s c h}}$ & $18.01 \mathrm{kWh}$ \\
Total Battery bank capacity: $C_{t b}$ & $C_{t b}=\frac{E_{s a f e}}{V_{b}}$ & $1500.8 \mathrm{Ah}$ \\
Total Batteries number in bank: $N_{t b}$ & $N_{t b}=\frac{C_{t b}}{C_{b}}$ \\
Series Batteries number: $N_{s b}$ & $N_{s b}=\frac{V_{d c}}{V_{b}}$ \\
Parallel Batteries number: $N_{p b}$ & $N_{p b}=\frac{N_{t b}}{N_{s b}}$ & 2 \\
\end{tabular}

Table 4. Charge controllers design and cost estimation.

\begin{tabular}{ccc}
\hline Parameter & Formula & Computed parameters \\
\hline Required charge controller: $I_{r c c}$ & $I_{r c c}=I_{s c}^{M} \times N_{p m} \times F_{s a f e}$ & $116.6625 \mathrm{~A}$ \\
$\begin{array}{c}\text { Number of charge controllers } \\
\text { (regulators): } N_{c c}\end{array}$ & $N_{c c}=\frac{I_{r c c}}{I_{c c}}$ & 2 \\
Cost of charge controllers: $C_{\text {tcost }}$ & $C_{\text {tcost }}=N_{c c} \times C_{c o s t}$ & US $\$ 1196.00$ \\
\hline
\end{tabular}

currents including motors were calculated as: $245 \times 3=735 \mathrm{~W}$ (inductive loads) (Table 5 and Table 6). 1.25 scale factor was used to multiply both inductive and non-inductive loads to allow for miscellaneous and possible system expansion [57]. The handling power for inverter becomes: $(1936+735) \mathrm{W} \times 1.25=3338.75$ W. The NIMTEK MM4000 Pure Sine Wave Off-grid Inverter was selected, a Solar Inverter with 4000 Watts, 24 Volt DC to 220 Volt AC, costing US\$660.00 [58]. 
Table 5. Cable selection.

\begin{tabular}{ccc}
\hline $\begin{array}{c}\text { PV system } \\
\text { cable link }\end{array}$ & Current Rating of the Cable & $\begin{array}{c}\text { Selected cable size } \\
\text { and Type }\end{array}$ \\
\hline $\begin{array}{c}\text { Cable from PV } \\
\text { array to battery } \\
\text { bank }\end{array}$ & $I_{c a b}=I_{r c c}^{M} \times N_{p m} \times F_{\text {safe }}=1166625 \mathrm{~A}$ & $\begin{array}{c}3 \times 35 \mathrm{~mm}^{2} \text { Insulated } \\
\text { Flexible Copper Cable }\end{array}$ \\
$\begin{array}{c}\text { Inverter to DB of } \\
\text { residential house }\end{array}$ & $I_{o i}=\frac{P_{i}}{V_{o i} \times P_{f}}=\frac{4000}{220 \times 0.8}=22.73 \mathrm{~A}$ & $\begin{array}{c}3 \times 4 \mathrm{~mm}^{2} \text { Insulated } \\
\text { Flexible copper cable }\end{array}$ \\
\hline
\end{tabular}

Table 6. Details on sizing and costing stand-alone solar power system.

\begin{tabular}{|c|c|c|c|c|c|c|c|}
\hline \multirow{2}{*}{ Component } & \multirow{2}{*}{ Model } & \multicolumn{3}{|c|}{ Component Rating } & \multirow{2}{*}{$\begin{array}{c}\text { Price/Un } \\
\text { it (US\$) }\end{array}$} & \multirow{2}{*}{ Quantity } & \multirow{2}{*}{$\begin{array}{l}\text { Total cost } \\
\text { (US\$) }\end{array}$} \\
\hline & & Size & A & $\mathrm{V}$ & & & \\
\hline Panels & $\begin{array}{l}\text { Znshine PV-Tech } \\
\text { ZX250(48)MS }\end{array}$ & $250 \mathrm{~W}$ & 5.14 & 24 & 375 & 17 & 6375.00 \\
\hline Batteries & $\begin{array}{c}\text { MK } \\
\text { 8A8DLTP-DEKA } \\
\text { 12V 245Ah AGM } \\
\text { Battery }\end{array}$ & $245 \mathrm{Ah}$ & - & 12 & 588 & 7 & 4116.00 \\
\hline Regulators & & - & 60 & 24 & 165 & 2 & 330.00 \\
\hline Inverter & $\begin{array}{c}\text { NIMTEK } \\
\text { MM4000 Pure } \\
\text { Sine Wave } \\
\text { Off-grid Inverter, } \\
\text { Solar Inverter } \\
4000 \text { Watt } 24 \\
\text { Volt DC to } 220 \\
\text { Volt AC }\end{array}$ & $4000 \mathrm{~W}$ & - & $24 / 220$ & 660 & 1 & 660.00 \\
\hline Wires & $\begin{array}{r}3 \times 4 \\
\text { Design, Lab }\end{array}$ & $\begin{array}{l}4 \mathrm{~mm}^{2} \text { Ins } \\
\text { pour, Met }\end{array}$ & $\begin{array}{l}\text { ated } \\
\text { ng, C }\end{array}$ & $\begin{array}{l}\text { xible Co } \\
\text { trol devi }\end{array}$ & $\begin{array}{l}\text { per Cable } \\
\text { ees }\end{array}$ & & 2313.00 \\
\hline & Total Estimated & Total cos & Freig & on Boar & $(\mathrm{FOB})$ & & $13,794.00$ \\
\hline & Carriage and fre & eight (C \& & )$(A s$ & ne $10 \%$ & f FOB) & & 1379.40 \\
\hline & Contingency (Assu & ime $5 \%$ o & ub-to & for $(\mathrm{FO}$ & $3+C \& F))$ & & 758.67 \\
\hline & Grand Tota & $\mathrm{al}(\mathrm{FOB}+$ & $\& \mathrm{~F}+$ & ntingen & & & $15,932.07$ \\
\hline
\end{tabular}

The house is located in a residential area where electricity tariff is US\$ 0.23/kWh. Then:

Annual savings $=10.463 \mathrm{kWh} /$ day $\times$ US $\$ 0.23 / \mathrm{kWh} \times 365=\mathrm{US} \$ 878.36$ saving per year

Payback period $=$ US $\$ 15932.07 / 863.325$ US $\$=18.13$ years.

\subsection{Grid-Tied Solar System Design and Cost Estimation}

The total energy requirement for typical residential house case study was 7204 Wh/day. Taking energy loss factor in solar system to be 1.3 [59], Wh/day needed from PV modules $=(7204 \times 1.3) \mathrm{Wh} /$ day $=9365.2 \mathrm{Wh} /$ day. Thus, for PV panel sizing, peak sun hours of 5 hours [3], direct system kilowatt size at STC = 
9365.2/5 =1873.04 Wp. Using Znshine PV-Tech ZX250 (48) MS module [54], number of modules required $=1873.04 / 250=7.49$ (approximately 8 ) modules. The total cost of modules, is: $8 \times$ US $\$ 375=$ US $\$ 3000.00$. Since loads are AC and assuming power factor of all appliances vary between 0.85 and 0.99 . Using, 1.18 multiplier to convert $1873.04 \mathrm{Wp}$ into VA [59]: VA output $=1.18 \times 1873.04$ Watts $=2210.18$ VA. The cost of grid-tied inverter which is able to support 2210.18 VA is US $\$ 210$ [61]. The cost of PV modules and inverter is: US\$3000.00 + US $\$ 210.00=$ US\$ 3210.00. Assuming 20\% of total cost as price of cables, net metering devices, labour, design and control devices, $20 \%$ of PV system total cost will be US\$ $3210 \times 0.2=$ US\$642 [62]. Thus, overall cost for grid-tied solar power system for typical house case study in Rwanda was US\$ $(3210+642)=$ US $\$ 3852.00$. This overall cost was regarded as Freight on Board cost (FOB) before shipment to Rwanda.

Assume Carriage and Freight $(\mathrm{C} \& \mathrm{~F})$ cost to be $10 \%$ of $\mathrm{FOB}=0.1 \times$ US\$3852.00 = US\$385.20.

Contingency (Assume 5\% of Sub-total for $($ FOB + C\& F $))=0.5 \times$ US\$ $4237.20=$ US\$ 211.86

Grand Total $($ FOB + C\& F + Contingency $)=$ US\$ $(385.20+211.86+3852)=$ US\$ 4449.06

Annual savings $=365 \times$ US $\$ 0.23 \times 9.3652=\mathrm{US} \$ 786.20$

Then payback period will be equal to US\$ $4449.06 /$ US $\$ 786.20=5.65$ years

\subsection{Reasons for Not Always Choosing Stand-Alone PV Systems}

According to [59], some drawbacks commonly associated with stand-alone PV systems include: 1) Batteries waste between $30 \%$ and $40 \%$ of costly solar power to charge inefficiencies, 2) Off-grid users waste or throw away surplus summer power, which is usually more than $50 \%$ of their requirements, 3) Batteries are unable to store more than $50 \%$ summer extra power for use in winter, when less than $50 \%$ solar requirements would be available, 4) During winter, lifestyle changes and adjustments to use less than 50\% normal summer solar average, are unavoidable, 5) Planning for battery maintenance throughout PV system's life, 6) Planning for batteries bank replacement every five (5) or so years, throughout home occupiers lives, 7) PV arrays must face specific direction (due East or West or South) at correct angle (This is not so with Grid-Tied), and 8) Need for back-up generator for long stretches of cloudy days, coupled with adjusting to aggressively increasing gas prices.

\subsection{Grid-Tied PV Systems Preference}

Whereas our analyses show grid connected PV solar system is the preferred choice, [39] and [59], suggest this preference from, using rule-of-thumb, which goes against tradition and convention in solar power usage. Furthermore, there are hardly any real requirements at majority of latitudes about exact roof facing. Also, consideration to avoid Trees and Shading [60], have been shown to have 
more impact than roof facing in Grid-Tied PV systems. In addition, East-West facing house roofs produce more Grid-Tied power than those facing the South [39].

\subsection{Grid-Tied Energy Economics}

Maheshwari and Bruninga [34] and [54] suggest producing excess $1 \mathrm{~kW}$ in summer feedback into the grid goes to feed nearest $1 \mathrm{~kW}$ load (neighbor). The power utility charges that neighbor and utility does not need to generate $2 \mathrm{~kW}$ worth of electricity, leading to avoided generation. Consequently, this translates to saving more than $4 \mathrm{~kW}$ energy of coal equivalent electricity for later use. In addition, utility does not need peaking units to meet peak demand, especially at normal prices. The economic benefits of Grid-Tied PV system include [34] [59] [63] [64]: 1) Homeowner wins by pushing meter $1 \mathrm{~kW}$ backwards, 2) Homeowner neighbour also wins by receiving $1 \mathrm{~kW}$ at standard electricity rate, 3) Power utility wins by avoiding costs of not burning $4 \mathrm{~kW}$ of equivalent coal or other fossil fuel units, 4) Utility does not need to buy $1 \mathrm{~kW}$ of electricity at exorbitant rates from neighbouring or adjacent utility, 5) Homeowner receives Solar Renewable Energy Credits (SRECs) for PV systems, 6) Environment also wins, from deferred burning of coal or other fossil fuels.

\subsection{Renewable Energy Feed-in-Tariff (REFIT) Policy}

The Rwandan REFITs are subjected to be reviewed by Rwanda Utilities Regulatory Authority (RURA) and other energy policy makers. REFITs policy for renewable energies, like solar, wind and geothermal are already in use but have not been issued and considered for Grid-Tied PV system [1] [65]. The motivations to install PV REFITs include: 1) Saving or earning money, 2) Increasing household energy independence, 3) Protection against higher future electricity costs, 4) Desire to improve environment, 5) Showing environmental commitment, and 6) Higher disposable income. Conversely, barriers to installation include: a) Lower disposable income, b) Age of customers, c) Likelihood of moving house within 5 years, d) Probability of losing money as they move house, e) Difficulty of obtaining reliable information, f) Aesthetics and neighbor approval, g) Uncertainty of potential system performance [66]

\section{Conclusion}

Cost-Benefit analyses were carried out on residential building in Rwamagana, Eastern Province of Rwanda, for the design and costing of stand-alone and grid-tied photovoltaic solar power systems, which supply $7.2 \mathrm{kWh}$ to all electric power appliances in household. The main factors affecting the design and sizing of each system component were considered. Analyses show grid tied solar system with US\$ 4449 initial investment, had 5.7 years payback period, while stand-alone power system with US\$15,932 initial investment, had much longer payback period of 18.1 years. Consequently, grid-tied solar system was found 
preferably cheaper than stand-alone solar system. Once smart grid technology is adopted by REG, coupled with setting up regulations and rules related to feed-in tariffs for this grid-tied solar system, and also by facilitating partners and energy investors in grid-tied solar power systems, Grid-Tied system can become one important solution for increasing electricity generation capacity in Rwanda, through solar electricity home producer-user groups.

\section{Acknowledgements}

This work was funded by the National Natural Science Foundation of China (program No. 51475136), Natural Science Foundation of Hebei Province, China (Program No. E2014202230), Universities in Hebei Province, China Science and Technology Research Youth Fund (Program No. QN20151002), University Innovation Team Leader Program in Hebei Province (LJRC003). Authors are thankful for the good collaboration between People's Republic of China and the Republic of Rwanda.

\section{References}

[1] Uhorakeye, T. (2016) Modeling Electricity Supply Options for Rwanda in the Face of Climate Change.

https://www.zhb-flensburg.de/fileadmin/content/spezial-einrichtungen/zhb/dokum ente/dissertationen/uhorakeye/dissertation-uhorakeye.pdf

[2] Kirai, P., Saini, A. and Hankins, M (2009) The Solar Market in Rwanda. https://www.giz.de/fachexpertise/downloads/gtz2009-en-targetmarketanalysis-solar -rwanda.pdf

[3] MININFRA (2014) Solar Energy in Rwanda. http://mininfra.gov.rw/index.php?id=85

[4] RDB (2017) Energy, Rwanda Development Board. http://www.rdb.rw/rdb/energy.html

[5] EPD-Rwanda (2013) Energy in Rwanda Overview of Rwanda Energy Sector. http://www.epd-rwanda.com/overview-of-rwanda-energy-sector-kigali.html

[6] MININFRA (2016) Rural Electrification Strategy. http://www.mininfra.gov.rw/fileadmin/user_upload/aircraft/Rural_Electrification_S trategy.pdf

[7] Maehlum, M.A. (2013) Grid-Tied, Off-Grid and Hybrid Solar Systems. http://energyinformative.org/grid-tied-off-grid-and-hybrid-solar-systems/

[8] Send, A. (2016) Solar Power. https://www.solarreviews.com/solar-power/

[9] Falk, A., Durschener, C. and Remmers, K.H. (2013) Photovoltaics for Professionals: Solar Electric Systems Marketing, Design and Installation. Routledge.

[10] Shoemaker (2012) Basics of Photovoltaic (PV) Systems for Grid-Tied Applications. https://www.pge.com/includes/docs/pdfs/shared/solar/solareducation/pv_basics.pdf

[11] Chu, Y. and Meisen, P. (2011) Review and Comparison of Different Solar Energy Technologies. Global Energy Network Institute (GENI), San Diego, CA.

[12] Barry, M.L., Steyn, H. and Brent, A. (2011) Selection of Renewable Energy Technologies for Africa: Eight Case Studies in Rwanda, Tanzania and Malawi. Renewable Energy, 36, 2845-2852. https://doi.org/10.1016/j.renene.2011.04.016

[13] Martinot, E., Chaurey, A., Lew, D., Moreira, J.R. and Wamukonya, N. (2002) Re- 
newable Energy Markets in Developing Countries. Annual Review of Energy and the Environment, 27, 309-348.

https://doi.org/10.1146/annurev.energy.27.122001.083444

[14] Centre for Sustainable Energy (2013) Guide to Going Solar. https://www.sce.com/wps/wcm/connect/f6f873d6-1e99-4f1d-9cd7-4a309c6c9800/C SI_Guide_To_Going_Solar_lo-res.pdf?MOD=AJPERES

[15] Environmental Impact Statement (2000) Solar Photovoltaic Technologies. http://solareis.anl.gov/index.cfm

[16] RuahaEnergy (2016) Solar Power Overview. http://ruahaenergy.com/solar/solar-overview/

[17] SEIA (2005) Photovoltaic (Solar Electric). http://www.seia.org/policy/solar-technology/photovoltaic-solar-electric

[18] Solardirect (2016) Sunlight to Electricity. http://www.solardirect.com/pv/systems/systems.htm

[19] Morley, T. (2015) Advantages and Disadvantages of Solar PV. http://www.greenpower-technology.co.uk/solar-pv/advantages-disadvantages-pv/

[20] Woodford, C. (2017) Solar Cells. http://www.explainthatstuff.com/solarcells.html

[21] Physics (2006) How Do Solar Cells Work? http://www.physics.org/article-questions.asp?id=51

[22] Google (2011) Photovoltaic System Charge Controllers and Linear Current Boosters. https://sites.google.com/site/reeetech/inverter/solar-charge-controllers

[23] Sumathi, S., Kumar, L.A. and Surekha, P. (2015) Application of MATLAB/SIMULINK in Solar PV Systems. In: Solar, P.V., Ed., Wind Energy Conversion Systems, Springer International Publishing, Berlin, 59-143. https://doi.org/10.1007/978-3-319-14941-7_2

[24] Hagerty, K. and Cormican, J. (2016) Components for Your Solar Panel (Photovoltaic) System.

https://www.altestore.com/howto/components-for-your-solar-panel-photovoltaic-s ystem-a82/

[25] Varkie, C.T. (2013) How Solar Electric Technology Works. http://energy-models.com/how-solar-electric-technology-works

[26] Watts, R.L., Smith, S.A., Dirks, J.A., Mazzucchi, R.P. and Lee, V.E. (1984) Photovoltaic Product Directory and Buyers Guide. Pacific Northwest Lab., Richland. https://www.osti.gov/scitech/servlets/purl/5061756

[27] Bijli Bachao Team (2016) What Is the Difference between Solar Inverter and Regular Power Inverter?

https://www.bijlibachao.com/solar/what-is-the-difference-between-solar-inverter-a nd-regular-power-inverter.html

[28] Nwwindandsolar (2015) How Do Solar Systems Produce Energy. http://www.nwwindandsolar.com/solar-power-in-seattle-and-the-northwest/how-d o-solar-systems-produce-energy/

[29] Jolly, S., Raven, R. and Romijin, H. (2012) Upscaling of Business Model Experiments in Off-Grid PV Solar Energy in India. Sustainability Science, 7, 199-212. https://doi.org/10.1007/s11625-012-0163-7

[30] Alternative Energy Tutorials (2017) A Stand Alone Solar System. http://www.alternative-energy-tutorials.com/solar-power/stand-alone-pv-system.ht $\underline{\mathrm{ml}}$ 
[31] Viscogreenenergy (2015) Solar Lighting Systems. http://viscogreenenergy.com/products/solar-lighting-systems/

[32] Welch, M. (2014) Batteryless \& Battery-Based Grid-Tied Systems. https://www.homepower.com/articles/solar-electricity/design-installation/batteryles s-battery-based-grid-tied-systems

[33] Walden Effect (2010) Plug and Play Grid Tie Inverters. http://www.waldeneffect.org/blog/Plug_and_play_grid_tie_inverters/

[34] Bruninga, B. (2009) Solar Grid-Tie or Off-Grid? http://www.aprs.org/off-grid-maybe.html

[35] Australiansolarquotes (2017) Types of Solar Power Systems. https://www.australiansolarquotes.com.au/buyers-guide/solar-power-systems/

[36] Luque, A. and Hegedus, S. (2011) Handbook of Photovoltaic Science and Engineering. John Wiley \& Sons, Hoboken.

[37] Tiwari, G.N. and Dubey, S. (2010) Fundamentals of Photovoltaic Modules and Their Applications. Royal Society of Chemistry.

[38] Rahim, N.A. and Mekhilef, S. (2002) Implementation of Three-Phase Grid Connected Inverter for Photovoltaic Solar Power Generation System. Proceedings International Conference on Power System Technology, Kunming, 13-17 October 2002, 570-573. https://doi.org/10.1109/ICPST.2002.1053607

[39] Asemota, G.N.O. (2010) Evidence-Based Wind-Felled Recovery of Plantains. African Journal of Plant Science and Biotechnology, 4, 78-83.

[40] Moore, D.S. and McCabe, G.P. (1993) Introduction to the Practice of Statistics. WH Freeman/Times Books/Henry Holt \& Co., New York.

[41] Montgomery, D.C., Runger, G.C. and Hubele, N.F. (1998) Engineering Statistics. John Wiley, New York, 149.

[42] Affordable-Solar (2016) Off-Grid System Sizing. http://www.affordable-solar.com/learning-center/solar-basics/off-grid-system-sizing/

[43] Lee, K.H., Malmedal, K. and Sen, P.K. (2012) Conceptual Design and Cost Estimate for a Stand-Alone Residential Photovoltaic System. Green Technologies Conference, Tulsa, 19-20 April 2012, 1-6. https://doi.org/10.1109/GREEN.2012.6200955

[44] Munro, K. (2010) Designing a Stand-Alone PV System. https://www.homepower.com/articles/solar-electricity/design-installation/designing -stand-alone-pv-system

[45] Farhat, K. and Reichelstein, S. (2016) Economic Value of Flexible Hydrogen-Based Polygeneration Energy Systems. Applied Energy, 164, 857-870.

https://doi.org/10.1016/j.apenergy.2015.12.008

[46] Corporate Finance Institute (2017) Discount Factor. https://corporatefinanceinstitute.com/resources/knowledge/modeling/discount-factor

[47] Bayarri, M.J. and Berger, J.O. (2004) The Interplay of Bayesian and Frequentist Analysis. Statistical Science, 19, 58-80.

[48] Raue, A., Kreutz, C., Theis, F.J. and Timmer, J. (2013) Joining Forces of Bayesian and Frequentist Methodology: A Study for Inference in the Presence of Non-Identifiability. Philosophical Transactions of the Royal Society, 1-18. https://arxiv.org/pdf/1202.4605.pdf

[49] Cole, S.R., Chu, H. and Greenland, S. (2014) Practice of Epidemiology-Maximum Likelihood, Profile Likelihood, and Penalized Likelihood: A Primer. American Journal of Epidemiology, 179, 252-260. https://doi.org/10.1093/aje/kwt245 
[50] Elf, M., Heisig, J., Schaeffer, M. and Shikamo, S. (2017) No Need to Turn Bayesian in Multilevel Analysis with Few Clusters: How Frequentist Methods Provide Unbiased Estimates and Accurate Inference. https://osf.io/preprints/socarxiv/z65s4/

[51] Bishop, C.M. (2006) Pattern Recognition and Machine Learning. Springer, Berlin.

[52] Asemota, G.N.O. (2009) On a Class of Computable Convex Functions. Canadian Journal of Pure \& Applied Sciences, 3, 959-965.

[53] Asemota, G.N.O. (2012) Optimal Two-Way Conductor Design Using Computable Convex Functions Approach. Advanced Materials Research, 367, 75-81. https://doi.org/10.4028/www.scientific.net/AMR.367.75

[54] Freecleansolar (2017) Znshine PV-Tech Solar Panels. https://www.freecleansolar.com/Znshine-PV-Tech-Solar-Panels-s/4458.htm

[55] Civicsolar (2017) MK 8A8DLTP-DEKA 12V 245Ah AGM Battery. https://www.civicsolar.com/product/mk-8a8dltp-deka-12v-245ah-agm-battery

[56] Wholesalesolar (2017) Morning Star Corporation TriStar TS-MPPT-60 Charge Controller.

https://www.wholesalesolar.com/3611105/morningstar-corporation/charge-controll ers/morningstar-corporation-tristar-ts-mppt-60-charge-controller

[57] Guda, H.A. and Aliyu, U.O. (2015) Design of a Stand-Alone Photovoltaic System for a Residence in Bauchi. International Journal of Engineering and Technology, 5, 34-44.

[58] Amazon (2017) NMTEK Solar Inverter. https://www.amazon.com/NIMTEK-MM4000-Off-grid-Inverter-Solar/dp/B00LYT2 6Q2

[59] Maheshwari, A., Jawaid, A., Mustafa, A. and Shakeeb, M.M. (2016) Design and Cost Estimation of a Grid Tied PV Module. International Conference on Power Electronics, Intelligent Control and Energy Systems, New Delhi, 4-6 July 2016, 1-3.

[60] Bimenyimana, S., Asemota, G.N.O., Kemunto, M.C., et al. (2017) Shading Effects in Photovoltaic Modules: Simulation and Experimental Results. 2nd International Conference on Power and Renewable Energy, Chengdu, 20-23 September 2017, 904-909.

[61] Alibababa (2016) Electrical Equipment \& Supplies. https://www.alibaba.com/premium/grid_tie_Inverter.html?src=sem_ggl\&cmpgn=4 $\underline{14357415 \& \text { adgrp }=25309597735 \& f d i t m=\& t g t=a u d-55680625111: k w d-103919398861}$ \&locintrst $=21178 \&$ locphyscl $=1012087 \& \mathrm{mtch} t y p=p \& n t w r k=g \&$ device $=c \& d v c m d l=$ \&creative $=112739588335 \&$ plcmnt $=\& p l \mathrm{cmntcat}=\& \mathrm{p} 1=\& \mathrm{pp} 2=\&$ aceid $=\&$ position $=1 \mathrm{t} 2$ \&gclid=Cj0KEQjwmcTJBRCYirao6oWPyMsBEiQA9hQPbr0X1JkG9fV-x4jw9m-q2 hMzdcpq81PUCnXV_8Uhj7MaAsSF8P8HAQ

[62] Pandey, R., Gaur, M.K. and Malvi, C.S. (2012) Estimation of Cost Analysis for $4 \mathrm{Kw}$ Grids Connected Solar Photovoltaic Plant. International Journal of Modern Engineering Research, 2, 4292.

[63] Asemota, G.N.O. (2015) Multivariate Parsimony Model for Electricity Load Management. 10 th Int. Conf. Energy and Environment, Recent Advances on Energy and Environment, Budapest, 12-14 December 2015, 77-86.

[64] Asemota, G.N.O. (2013) Electricity Use in Namibia: Developing Algorithms to Encourage More Efficient Consumer Behaviour and Motivate More Environmentally Friendly Utility Practices. iUniverse, Bloomington.

[65] Energypedia (2018) Rwanda Energy Situation. https://energypedia.info/wiki/Rwanda_Energy_Situation\#Renewable_Energy_Feedin_Tariff 
[66] Balcombe, P., Rigby, D. and Azapagic, A. (2014) Investigating the Importance of Motivations and Barriers Related to Microgeneration Uptake in the UK. Applied Energy, 130, 403-418. https://doi.org/10.1016/j.apenergy.2014.05.047

[67] Bickel, D.R. (2011) Blending Bayesian and Frequentist Methods According to the Precision of Prior Information with an Application to Hypothesis Testing. https://arxiv.org/pdf/1107.2353.pdf 